\title{
Impacts of Colonialism on Religions: An Experience of South- western Nigeria.
}

\author{
Ahamad Faosiy Ogunbado, Ph.D. \\ ${ }^{I}$ (School of Humanities \& Social Sciences, Albukhary International University, Alor Setar, Kedah, Malaysia).
}

\begin{abstract}
Exploitation by a stronger country of weaker one or the use of the weaker country's resources to strengthen and enrich the stronger country is what is termed as colonialism. Henceforth, many parts of the world in general and African continent in particular experienced this phenomenon. Nigeria as one of important countries in Africa experienced exploitation between 1861 and 1960 under the Great Britain. Its advent had impact on many things such as politics, economy, religion, education and social set up of the country. Therefore, the paper intends to explore the impact of this phenomenon on religions in south-western Nigeria. The paper discusses the two religions (Traditional and Islam) which had been known in this region long before the period of colonialism. It also looks into the negative and positive of its impacts. It hashes out various resistances from the masses and how British government overpowers them. The paper is library-oriented research which means data and materials are drawn from books, articles, magazines and relevant websites. In other words, qualitative research methodology is used. Among others, the finding shows that there are two religions on ground before the advent of colonialism. It also shows that the advent of colonialism added another religion which is known as Christianity to the existing ones. It also discovered that the negative outweigh the positive impacts.
\end{abstract}

Keywords: Christianity, Colonialism, Impact, Islam, Religion, Yoruba Traditional.

\section{Introduction}

Colonialism is a phenomenon that continents such as Africa and Asia in particular experienced from hands of Europeans major powers. It is defined as exploitation by a stronger country of weaker one or the use of the weaker country's resources to strengthen and enrich the stronger country. (Worldweb OnlineDictionary, n.d). It is also said to be a situation whereby a powerful country rules a weaker one and establishes its own trade and society there. (Longman Dictionary, 2000).

The Phenomenon came into existence as a result of many reasons: (1) Abolition of slave trade which was intensified during $17^{\text {th }}$ and $18^{\text {th }}$ century necessitated searching for legitimate trade. (2) Emergence of industrial revolution brought in higher demand of raw materials for the industries which the local agriculture was incapable to meet. (3) Necessity of finding markets for the European countries' factory productions. (4) Urbanization: the increase in urban population and decrease in rural and agricultural production ushered in high demand for food production to satisfy the swelling growth of the urban cities of European countries. It is noted that:

In Berlin conference of 1884-1885, European powers gathered together and determined African fate. Great Britain, France, Germany and Portugal were the major players in this three months conference that ended in dividing African continent among the European colonial masters and superimposed artificial boundary on its subjects. (De Blij \& Peter, 1997:340).

The Berlin conference was Africa's undoing in many ways than one. The colonial powers superimposed their domain on the African continent. By the time independence returned in 1950s, the realm had acquired a legacy of political fragmentation that could neither be eliminated nor made to operate satisfactorily. Nigeria, the so called "the giant of Africa" and "the biggest black nation of the world" is an important nation in Africa that suffered this phenomenon. In fact, the name "Nigeria" itself was coined by the colonial master, after the distortion of established and natural boundaries which was replaced with the artificial ones to suit their benefits. South-west of the country is predominantly domiciled by the Yorubas. In Nigeria or rather in West African countries, the Yorubas are considered to be the largest cultural aggregation with a history of political unity as well as a common historical tradition. (Coleman, 1971). The name "Yoruba" is the name of the people as well as their language. Hence, this paper aims at looking into the impacts of the colonialism on religions in the region domiciled by these people. It talks about the religions (traditional and Islam) on grand before the advancement of the intruders. It divides the impacts into two: negative and positive and expatiates each of them. It also exhibits some resistance from various groups and how the British mighty overwhelm them. 


\section{Religions in the Region before the Colonial Era}

What is the religion?

No single definition can be ascribed to the world religion due to their diversity. Many people considered religion as "an organized system of beliefs, ceremonies, practice and worship that centre on one supreme God, or the deity." To many others, "religion involves a number of gods, or deities."(The world book encyclopedia,1990, 16:196-197). In some religions no particular God or gods are worshipped. Religion is also considered to be "collection of cultural systems, belief systems, and worldviews that relate humanity to spirituality and, sometimes, to moral values." Whatever the diversity it entails, most adherents of some forms of religion believe that the world is created by a divine power and has influence on their lives. In other words, most religions shared wholly or partially some characteristics which include: (1) belief in God or deity, (2) a doctrine of salvation, (3) a code of conduct or ethics, (4) the usage of sacred stories (5) rituals or religious acts and ceremonies. (Ibid).The religions in south-west Nigeria have no exception in this category. The religions in south-western Nigeria before the coming of colonial master are two: traditional religion and Islam which will be explained afterwards.

At this juncture, it is important to add that we cannot segregate the word religion from culture as we can see from the last definition which defines religion as "collection of cultural system.....". This is well explained in the word of America sociologies quoted by Amponsah which defined culture as:

a collective name for all behaviour patterns socially acquired and socially transmitted by means of symbols; hence a name for distinctive achievements of human groups, including not only such items as language, tool making, industry, art, science, law, government, morals and religion, but also the material instruments or artefacts in which cultural achievements [sic] are embodied and by which intellectual cultural features are given practical effect, such as buildings, tools, machines, communication devices, art objects, etc. (Amponsah, 2010:597).

\section{Yoruba Traditional Religion}

Religion is fundamental and has tremendous influence in the life of the people of south-western Nigeria, i.e the Yorubas. All their endeavours have to do with religion. Therefore, it is pertinent to say here that it is difficult to segregate Yoruba religion from Yoruba culture. Doi in one of his works observed this and states:

There is no event in the life of the Yoruba without any religious significance. From cradle to grave he is incurable religious. The religion of Yoruba could not be really understood by any outsider unless he becomes intimately associated with the people, their ways of life and their religious principles. (Doi, 1992:121).

Another author conceived the same notion about the Yoruba traditional religion when he was talking about Africa traditional religion in general in his article. He articulates:

Religion is a fundamental, perhaps the most important, influence in the life of most Africans; yet, it's essential principles are too often unknown to foreigners who thus make themselves constantly liable to misunderstand the African worldview and beliefs. Religion enters into every aspect of the life of the Africans and it cannot be studied in isolation. Its study has to go hand-in-hand with the study of the people who practise the religion. (Awolalu, 1996:1).

In Yoruba traditional religion, people believe in the existence of Almighty God which they call Olorun (Lord of Heaven) or Olodumare (the supreme God worth of great reverence). Sometimes, they combined both words Olorunolodumare and used it as a compound noun to express the Supreme Being who stays in the Heaven. However, they worship many deities as intermediaries who can link them to God of Heaven. Because, they thought that God of heaven cannot be reached directly. This idea was developed from the respect that they had for their kings. The hypothesis is, if their kings cannot be seen directly, then, Oba awon Oba (King of Kings) cannot be easily reached without a connection. Those intermediaries that link them to the Almighty are known as Orisas. (Johnson, 1921, reprinted ed. 2001) and (Ogunbado, 2010).

The Orisas or Deities are numerous, Ogun, Sango, Obatala, Esu, Oya, Osun, Yemoja, to mention but few. Each city, village or community in south-western Nigeria has specific Orisas which they worship. In some cases, different names are assigned to a particular deity in various locations. For instance, Orisala is called Oluofin at Iwofin. The same Orisa is known as Orisako at Oko. It is also known as Orisagiyan at Ejigbo, while it is called Orisakire at Ikire. It is also called Orisaowu at Owu and Orisajaye at Ijaye. 


\section{Islam}

Islam is another religion that had well established itself in South-west before the advent of colonialism. Islam is a monotheistic religion that lay it foundation on the oneness of God. Islam is an infinitive form of the word aslama which means 'to resign oneself', to profess Islam. (Hastings, Selbie \& Gray, 1908) The term is also derived from the Arabic word "slm" which means peace, purity, submission and obedience. The word is simply defined as pious submission to the will of God, or "Surrender to the will of Allah." It is also defined as "the complete acceptance of the teachings and guidance of God as revealed onto His Prophet Muhammad" (s.a.w). (World Assembly of Muslim Youth, n.d).

It is very difficult to precisely ascertain the actual date of the coming of Islam in south-western Nigerian because it was "unannounced and unplanned." Likewise, the earlier Muslims in the area under study worshiped secretly and privately. (Gbadamosi, 1978). However, it is learnt that Islam had been practiced and a mosque had been erected as far back as 1550 C.E at Oyo-Ile. (Al-Aluri, 1990). It is even recorded that influence of Islam had been felt around the same time which happened to be the time of Alaafin Ajiboyede. A clergy man known as Baba Kewu sent his emissary to the King, so as to "remonstrate with him for his unjust and cruel acts avenging his son's death on innocent people when his son has died a natural death." (Johnson, 1921, reprinted ed. 2001:164). Al-Aluri (1965) also suggests that Yoruba knew about Islam during the time of Emperor Mansa Musa of Mali (d1337 C.E) through the Malian traders and ambassadors who were living in Oyo-Ile, the capital of Old Oyo empire. This is perhaps, a reason why some people call "Islam" as "esin Imale" i.e. "the religion of Malians" or "the religion that came from Mali."

Islam quickly gained ground in Yoruba land and both religions had been co-existed centuries before intrusion of white men. This could be traced to some of Islamic teachings that are concurred with Yoruba traditional religion and culture. For instance: (1) traditional religion believes in the existence of Supreme Being which coincides with the belief in Islam. However, there is difference in its application. While Yoruba traditional religion worships Orisas as intermediary, Islam opposes the teaching vehemently. (2) Both religions sacred marriage and accepted polygamy. However, in traditional religion, the institution is limitless while Islam limits it to four at a time. (3) Morals and values such as modesty and respect are part and parcel of the both religions.

Probably, because of harmony, tranquillity and co-existence between both religions for a long period of time, the Yorubas assumed both as ancestral religions this is echoed in one of their folksongs.

Aye laba Ifa, Aye laba Imole

Osan gangan ni'gbagbo wole de

We met oracle in the world

We met Islam in the world

It was late in the day that Christianity arrived.

\section{The Advent of Colonial Masters, Christianity and Western Education}

The incursion of white men into the entity known as Nigeria can be attributed into two phases. The first phase was in fifteen century, in the wake of geographical discoveries and when the European explorers were set on the sea seeking the route to India. The Portuguese reached Benin in about 1477. (Erivwo, 2012). As early as 1472, says Fafunwa (2002), Portuguese merchants reached Lagos and Benin. In 1485, the merchants have engaged the people of Benin in pepper trading and Oba (King) of Benin sent an envoy to the Portuguese royal court.

Perhaps, the Portuguese were initially concerned with the trade but they conceived that Africans had to be civilized so as to become a good customer. To be civilized, according to them, is to be Christianised and have rudiment Western education. The missionary activities started in Benin in 1515 by Catholics Missionaries and established a school for converted princes and children of notable chiefs in Oba's palace. (Ibid). In the same year, Gasper, the bishop of the Diocese of Sao tome sent Augustinian monks to visit Warri. Consequently, a son of Olu of Warri was baptized with given name Sebastian. Afterward, Sebastian succeeded his father and gave Portuguese missionaries enormous support and his son Domingos was sent to Portugal to be trained for the priesthood. Despite all these, there were other obstacles that outweighed the favour and which led to the abandon of the project. Second phase and the beginning of everlasting impacts began in September 1842 when the first British Christian mission landed at Badagry. The librated slave from Sierra lone had been engaged in trading with Yoruba region and spreading Christianity and the first established church was dominated by those ex-slaves. The missionaries, however, were the custodian of education which was a tool for conversion. Because education by then aimed at producing Christians who can read Bible and perform services. William Boyd is quoted:

...it must be kept in mind that the church undertook the business of education not because it regarded education as good in itself, but because it found that it could not do its own proper work without giving its adherents, and especially its clergy, as much of the formal learning as 
was required for the study of the sacred writings and for the performance of their religious duties. (Fafunwa, 2002:70).

It can be deduced from this segment that the advent of colonial masters led to the introduction of new religion, Christianity, which is added to the two available religions, Yoruba traditional religion and Islam. Likewise, the western type of education crept in through the coming of Christianity. Obviously and without exaggeration, all these had impacts positively or negatively on religions on the ground. As it could be inferred from earlier discussion, the notion of religion in this paper does not limited to rituals only but also includes culture, economic, politics and other aspects of human endeavours as Islam claimed it. However, the economical and political aspects, for instance, will be investigated from religious perspective not from the economist or political scientist perception.

\section{Positive Impact of Colonialism in South-western Nigeria.}

Advent of colonial masters necessitates the coming of a new religion into the region. That is to say, the Christianity which was believed to be religion of the whites (Esin awon Oyinbo) was introduced. The coming of Colonialism and its concomitant Christianity helps to abrogate ritual with human being or human sacrifice. In order words, the phenomenon help to put an end to some of the traditional religion rituals conducted by sacrificing human being to appease the gods.

The arrival of colonialism coupled with appearance of Christianity brought the Western education which is considered as vehicle of prosperous civilization. Uniform was introduced and school boys and girls had to dress, behave and speak like Europeans.

The coming of whites especially before the abolition of slave trade boosted economical status of the kings as well as some dignitaries who collaborated with the whites in slave trade. This helped in transporting Yoruba traditional religion to the Latin America such as Brazil and Cuba. It can also be seen after the imposition of ban on slave trade that seeking the legitimate trade also puffed up the saving of the merchandisers who served as intermediary between the British traders in the coast and the peasant in interior land.

The incursion of colonial masters led to the availability of transport networks. The railway was introduced first in south-western Nigeria. It started from Lagos in 1896 and reached Abeokuta in 1900. A year later, it reached Ibadan and by 1909 it linked the border of the northern Nigeria.(Olubomehin, 2001). Beside railway, roads were also constructed. The first road was built in 1906 from Oyo to Ibadan so as to link with the railway line. In 1907 another 30 miles was constructed linking Oyo to Ogbomoso and 27 mile road from Oyo to Iseyin. By 1910 and upwards, Ikirun to Ila, Osogbo to Ilesa and so on were constructed. (Ibid.). It also ushered in other social amenities such as hospital, electricity and so on. However, looking into these so called positive impacts could be proved negative, if they were to be scrutinized as the following phase will expose it.

\section{Negative Impacts of Colonialism}

Colonialism brought negative impacts into the existing religions through the introduction of new religion (Christianity), both Yoruba traditional religion personnel and Muslim felt threatened. Missionaries were converting many traditionalists and Muslims into the new religion, while these actions caused havoc among the followers of the same religion. Yoruba rulers who were the custodian of the traditional religion and Muslim clergies did not fold their arms and allowed their religion respectively to be castrated. They put efforts to resist the conversion. However, both the Colonialists and Missionaries worked together to subdue the existing religions. This could be inferred in the Fafunwa's statement. (2002:71). "The missionaries depended on the Europeans for help to in keeping the rebellious African Chiefs in their place, while the European authorities hoped to conquer by religious persuasion what they failed to achieve by force of arm." Perhaps, it could also be comprehended from this statement that the introduction of the Christianity by the Colonial master was not for the religious sake -not for their love for father or son or holy spirit- but to achieve the hegemony.

It could also be argued that the introduction of the Christianity is aimed to completely up-root the existed norms as it is said that "the primitive religions are all destined to be perish and disappear." (Kraemer 1938: 230). The following quotation also speaks voluminously.

The missionary is a revolutionary and he has to be so, for to preach and plant Christianity means to make a frontal attack on the beliefs, the customs, the apprehension of life and the world, and by implication (because tribal religions are primarily social realities) on the social structures and based of primitive society. The missionary enterprise need not be ashamed of this, because colonial administration, planters, merchants, western penetration, etc., perform a much more severe and destructive attack. (Ibid., p342).

It is mentioned earlier that Colonialism and Christianity brought in Western education and civilization. However, it is now proved that negative side of it preponderates the positive side in the sense that (1) the school was used as an instrument of conversion, that is, to convert the beneficiaries into Christianity. (2) It seems that 
Western education and its religion focused on spiritual and some aspect of social life. Therefore, little or no emphasis was laid on other human endervours such as interpersonal morality and societal norms. Likewise, the concept of Western religion concentrated on belief than practice. (3) Western or Colonial education was fundamentally literary, which based on reading writing, arithmetic, Bible knowledge, Christian literature and so on, which all aimed to produce Christian who can read Bible and serves as clerks, agents and interpreters for Colonial masters and facilitate their trade. (4) Western/Colonial education relegated the existing education into the oblivion. For instance, before the advent of Western education, Arabic/Islamic Education was flourished and the Yoruba language was written in Arabic alphabets known as ajami. This was raped off and substituted with Roman alphabets that is been used till today. Traditional education system also paved way for moral and other form of education available outside school while in Western education, the system of boarding accommodation denied them such golden opportunity. (Omotosho, 1998) and (Ogunbado, 2011).

It is also claimed that slave trade helped to spread the Yoruba traditional religion beyond the locality and boosted the economy. It is argued that those slaves who were taken to the foreign land were forcibly transported so as to work on their masters' farm. They were not even allowed to practice their religion they were been converted to Christianity. Only few of them remained in their religion and were able to practice it after their freedom. Most of them were even died on the way and were thrown into the ocean. Apart from that, the departure of the slaves from their home was disastrous to their family and community because they were the pillars and able bodies (working force) in their community. It was only the economic status of the collaborators that were boosted and they were minority while the majority suffered the consequence.

Although, it is mentioned that social amenities were introduced by the colonial administration. Scrutinizing this claim showed that they are all for selfish intentions. For instance, in transportation network, the train were built to easily convey the raw materials from the source to the coast where they will be shipped to Europe. The area connected were major cities, markets and coasts. Likewise, the roads were built not for the people's convenience but to allow the British officers to move in the interior land to supervise toll and taxes collection. Roads were also built to serve as feeder to the railway terminus. In other words, the roads were constructed to ease the carrying of raw materials from interior land to the railheads, since rail did not cover the whole interior. It is even alleged that most of the early roads were based on the old foot-path that linked villages with farms and market. The colonial masters just widened and straightened them; some of them were not even tarred. (Omotosho, 1998). The colonial government at initial stage even opposed the construction of the rail because of its expenses. However, the money spent on the project was raised through taxes. The element of religion enslavement can also be seen in the aim of the project, as one of the exponents of the network uttered and quoted in Coleman (1977: 55): "Think of the benefit that it would be to England in increasing markets for manufactured goods and receiving additional produce in return,... it would civilize the savage and prepare him for the missionary".

Under the pretext of civilisation, the British disarrayed traditional institutions and religious culture. They rubbed Obas (Kings) of their rights; relegated them and made them to be subordinates to the white dominance. An artificial boundary was introduced to replace the natural and cultural one. Hence, the Yorubas were divided between the British dominance in Nigeria and French Imperialism in Benin.

\section{Resistance and Coloniser's Responses or Atrocities}

As a matter of fact, no community or society will fold its arm and simply allow the foreign domination over its father's land. So did, Yorubas in south-western Nigeria. In other words, Yorubas did not simply succumb to the imperialism; they did not just allowed all these negative impacts to be staged at once, or permit disorderliness of their traditional institutions and religious culture. They exhibited some resistances. However, the British and other colonial masters in Africa had decided to use excessive force to overwhelm the traditional rulers and their subjects who were resisting the European dominance in their respective places. The British employed the same tactics to subdue the Yorubas in south-western Nigeria.

The colonisation of south-western Nigeria in particular and the entire nation in general started from Lagos which happens to be a coastal city in south-western Nigeria. Imperialism began with designing anti-slave trade treaty which was to be signed by the African rulers. Whoever denied signing it will be dealt with. The Oba of Lagos, Kosoko was first approached to sign the treaty.

Oba Kosoko viewed the treaty as an incursion on his land's affairs and thus denied to sign it. The British started to plot against him and his supporters. In November, 1851, John Beecroft tried to persuade Kosoko to sign but he failed in his mission. Afterwards, he ordered his accompanied four warships to fire Lagos. Kosoko and his men showed courage and fired back which claimed two officers' live and injured other sixteen people. (Ikime, 1977). This resistance and retaliation was seen as a disgrace to the British who retreated only to come back with full force to bombard Lagos on $26^{\text {th }}$ December, 1851. Eventually, Kosoko was banished from Lagos. His rival to the throne, Akintoye was crowned and signed the treaty. Few months later, Lagos became a 
British colony. However, Kosoko who happened to be a Muslim and his followers re-established their religion and institution in Epe.

Having succeeded in overwhelming Lagos, the British traders and the authority in Lagos (a British colony) then wanted to have direct interaction or free access to the interior and intended to sideline the Ijebus who had been served as middlemen. They also wanted to spread the Christianity into the Yoruba interior. Ijebus on the other hand did not want any hindrance in their business and perceived this intention as an encroachment on their sovereignty. As a result, the Ijebus staged a hostility demonstration to the acting colonial governor's visit in 1889. The colonial authority considered the Ijebus action as an insult and demanded an apology. When an Awujale delegation was sent to Lagos to welcome the new governor, the delegate was coerced to sign a treaty which was furiously rejected. The colonial authority capitalised on this rejection to invade the Ijebus. On the $19^{\text {th }}$ May 1892, there was fierce battle, the Ijebus put up a patriotic defence. Nevertheless, they were crushed due to the British mighty weapons.

In December, 1893, Captain Robert Lister Bower assumed duties in Ibadan as the first Resident and Travelling Commissioner in the hinterland of Yoruba land in south-western Nigeria. Among his duties is to enforce the treaties and to consolidate the British authority in the area. His dealings began with intimidating and bullying the Ibadan chiefs so as to let them subscribe to the British imperialism. The Balogun of Ibadan, Chief Akintola was arrested 1894 during a traditional festival. The Osi Baale, Chief Fajimi was also arrested. Prior to that, Chief Sanusi was arrested. Those chiefs were held responsible for the confrontations of their subordinates to the British officials. (Ajayi, 2008). A leader of Ekitiparapo -a resistance group- chief Ogedengbe and his boys were detained and later exiled the leader to Iwo.

Captain Bower was not happy with the refusal of Alaafin of Oyo and his people to the British imperialism. The Alaafin was exercising his role as paramount ruler in Yoruba Land. Therefore, surrender to the "Oyinbo" whites was seen as an affront to his institution and culture. However, the resident seized an opportunity to shell Oyo, when Alaafin passed a judgement to castrate a man that had intercourse with the wife of Aseyin of Iseyin. Bower perceived the pronouncement as "barbaric" and ordered Alaafin and his chiefs to prostrate before him at the city market. The Alaafin furiously refused the order. Aseyin was tied and lambasted publicly. Afterwards, Oyo Alaafin was bombard in 1895. (Ibid.) and (Lasisi, 1997). In Oyo Alaafin as much as the same in Ibadan and other major cities in the south-western Nigeria, the people revolted against the imperialism in one way or the other. They even denied Western education which was an instrument of conversion. Rev. G. Burton of Oyo on December, $5^{\text {th }} 1910$ wrote:

In the Western section of the Yoruba mission Mohammedanism is gaining ground rapidly. In

Oyo, Ogbomoso, Iseyin Christianity is making very little progress, but everywhere Mohammedanism mosques are to be found. It is no comfort to reflect that this Mohammedanism is of a very crude nature. The very ignorance of its followers makes work amongst them exceptionally hard and discouraging. There are several Mohammedan schools in Oyo now, and it is by no means an uncommon sight to see children carrying their 'slates' of Arabic texts, which they learn to repeat parrot-fashion. (The Muslim World, 1911: 351).

Similarly, a missionary teacher, Anna wrote down in her diary on the $1^{\text {st }}$ of October 1853 , about the response of Ibadan people to the Western education and quoted in Fafunwa (2002:61 and 85) thus: "Our School does not increase at present, people are afraid to send their children; they think "book" will make them cowards, but those we have are going on nicely".

\section{Conclusion}

Colonialism is an issue that will never be forgotten in Nigeria at large and south-west of the country in particular due to its impacts that lingered after its disappearance. It is defined as exploitation by a stronger country of weaker one or the use of the weaker country's resources to strengthen and enrich the stronger country. It came to limelight due to the abolition of slave trade, emergency of industrial revolution and the search for new market for the manufactured goods and so on. The impacts of this phenomenon are manifested in many aspect of colonised people's life. However, the paper confined itself to the impacts on religion. The religion as conceived here is not restricted to the rituals but wider in it's scope to accommodate culture.

There are positive as well as negative impacts. The former includes, Introduction of new religion, advent of Western education and civilisation, abrogation of human sacrifice, transportation network, electricity and other social amenities. The latter includes torturing the existed religions, distortion to the traditional tribal cultures, norms and values. It also includes introduction of artificial boarder, subjugation to alien authority and use of most sophisticated weapons of the day to intimidate people and confrontation on the traditional institutions and the act of dictatorship of the colonialist to force the traditional leaders to become submissive of imperialist treaty for colonial interest. 
The resistance from the various groups or cities shows that the Yorubas did not just fold their arms and sacrifice their authority to foreign rule. There are lot of patriotic and courageous people that laid their life defending their lands and authority. They were crushed by the mighty of Oyinbo. The remembrance of these people is necessary. It is opinion of the writer that the British and other colonial masters should find one way or the other to compensate their colonies for the distortion they caused them.

\section{References}

[1] Wordweb online dictionary.

[2] Longman dictionary of contemporary english.

[3] De Blij H.J. and Muller P. O, (1997). Geography: Realms, region, and concept. N.p :John Wiley \& Sons, Inc.

[4] Coleman, J. S. (1971). Nigeria: Background to Nationalism. Berkeley: University of California Press.

[5] http://www.thefreedictionary.com/Yorubas (accessed 3-March-2012).

[6] The World book encyclopedia, vol 16:197.

[7] http://en.wikipedia.org/wiki/Religion (accessed 5-March-2012).

[8] Amponsah, S. (2010). "Beyond the boundaries: Toyin Falola on African cultures" in Niyi Afolabi, (Ed). Toyin Falola: The Man, the mask, the muse. North Carolina: Carolina Academic Press.

[9] Doi, A. R. I. (1984). Islam in multi-religious society. Nigeria: A case study. Kuala Lumpur: A.S. Noordeen.

[10] Awolalu, J. O. (1996). "What is African Traditional Religion?" Studies in Comparative Religion, Vol. 10, No. 2:1. (C) World Wisdom, Inc. www.studiesincomparativereligion.com.

[11] Johnson, S. (1921, reprinted ed. 2001). The History of the Yorubas. Lagos: CSS Press.

[12] Ogunbado, A. F. (2010). Islam and its impact in Yoruba land (South-west Nigeria). Paper presented at The Fourth International Malaysia-Thailand conference on Southeast Asian Studies. Co-Organized by UKM-MAHIDOL. On 25-26 March 2010. At Bangi, Malaysia.

[13] Hastings J., Selbie J.A. and Gray L., (1908) Encyclopedia of religious and ethics. Edinburgh: T\&T Clark.

[14] World Assembly of Muslim Youth, (n.d). Islam in concert, Riyadh: The Cooperative office for call and guidance

[15] Gbadamosi, T. G. O. (1978). The Growth of Islam among Yoruba, 1841-1908. London: Longman Group Limited

[16] Al-Aluri, A. A. (1990). Nasimu al-soba fi Akhbar al-Islam wa 'Ulamah bilad Yoruba. Cairo: Maktaba Wahaba.

[17] http://www.alaafin-oyo.org/main/alaafin/genealogy. (accessed 6-June-2011).

[18] Al-Aluri, A. A. (1965). Mujiz tarikh Nigeria. Beirut: n.p.

[19] Erivwo, S. U. (2012). History of Christianity in Nigeria, the Urhobo, the Isoko and the Itsekiri. http://www.waado.org/UrhoboCulture/Religion/Erivwo/HistoryOfChristianity/ChapterOne.html. access 5-march- 2012

[20] Omenka, N. I. (1989). The School in the Service of Evangelization: The Catholic educational impact in eastern Nigeria 1886-1950. Leiden, E.J. Brill.

[21] Fafunwa, Babs. (2002). History of education in Nigeria, Ibadan: NPS Educational Publishers Ltd.

[22] Olubomehin, O. O. (2001). The development of road and road transport in South-Western Nigeria, 1906-1920. NJEN No 4: 14-24. www.ajol.info/index.php/njeh/article/viewFile/36492/25497 (accessed 5-March-2012).

[23] Kraemer, H. (1938). The Christian message in a non-Christian world, London: Harpers.

[24] Omotosho, A. O. (1998). The impact of colonial education and culture on the Muslim of Nigeria. Journal of Arabic and Islamic Studies, April/May 1998. Pp52-61.

[25] Ogunbado, A. F. (2011). Muslim Education in Oyo Alaafin: Challenges and developments. Paper presented at International Conference on Islam in Africa: Intellectual Trends, Historical sources and Research Methods. Co-organized by The Federation of the Universities of the Islamic World (FUIW), International Islamic University Malaysia (IIUM), and Islamic Educational, Scientific and Cultural Organization (ISESCO).19th -21st July, 2011.

[26] Ikime O., (1977). The fall of Nigeria: The British Conquest, London :Heineman.

[27] Ajayi, S. A. (2008). Bower tower: A historical monument in Ibadan, Southwestern Nigeria. The Social Science 3 (1) 2008: $45-50$.

[28] Lasisi, R. O. (1997). "Muslim Traditional Rulers in Nigeria: The Alaafin of Oyo during the Last Phase of British Colonialism, 1945-1960." Journal of Muslim Minority Affairs, Vol 17, No. 1, 1997: 31-41.

[29] The Muslim World, Vol. 1, No.3 July 1911. 